\title{
BIOAVAILABILITY RESEARCH OF SOLID MEDICINAL FORMS BY THE EXAMPLE OF BISOPROLOL FUMARATE TABLETS IN RELATION TO THE BIOPHARMACEUTICAL CLASSIFICATION SYSTEM
}

\author{
S.M.Gureeva \\ "Farmak" Joint-Stock company \\ Key words: biopharmaceutical classification system; solid medicinal forms of industrial production; \\ kinetics of release; physical and chemical properties of active substances; biowaiver; bioequivalence
}

The place and role of the biopharmaceutical classification system have been substantiated in the article, the essence and content of biowaiver have been revealed, as well as their use in pharmaceutical development of bioequivalent solid dosage forms has been described. A new direction has been presented. It is discovery and study of physical and chemical regularities of using active pharmaceutical ingredients, which influence on their pharmacological action. The dependence of the active substance on technological factors, i.e. features of the pharmaceutical technology, has been studied. It has become possible due to the use of modern perfect methods of estimation of drug efficiency and mainly the possibility of determination of the content of active substances and their metabolites in biological fluids, and it is necessary when considering a question about the therapeutic equivalence of medicines. On the example of the active substance - bisoprolol fumarate, which belongs to class I in accordance with the biopharmaceutical classification system, the kinetics of release and bioequivalence have been studied. The kinetics of release of the active substance of $10 \mathrm{mg}$ tablets of bisoprolol fumarate and the corresponding original medicine "Concor tablets, $10 \mathrm{mg}$ " has been studied in the $\mathrm{pH}$ medium of $1.2 ; 4.5 ; 6.8$. It has been proven that development of a new medicinal form is a difficult process of the experimental research, therefore, for optimization of development of the composition and technology of medicines under conditions of the laboratory of industrial pharmacy it is necessary to use the most effective methods and methods of biopharmaceutical research, one of which is the research of bioequivalence of solid dosage forms based on the study of physical and chemical properties of active substances using the biopharmaceutical classification system.

At the present stage of development of the pharmaceutical industry scientists are trying to establish the dependence of action of drug substances on technological factors, i.e. features of the pharmaceutical technology. It has become possible due to the use of modern perfect methods of estimation of drug efficiency and mainly the possibility of determination of the content of active substances and their metabolites in biological fluids, and it is necessary when considering a question about the therapeutic equivalence of medicines. The results of this research are widely used to improve the efficiency of medicines and reduce their side effects.

For optimization of research of technological and biopharmaceutical indicators of active substances depending on their physical and chemical properties the drug classification systems are used in pharmacy; they are used as means to establish relationships or orientation in various notions of the corresponding objects performing the fuction of the unified description of the range of medicines that are present at the pharmaceutical market in order to compare the volume of their consumption at the national or international levels. Classification systems compare standardized and validated information on the use of a medicine to check and determine the structure of consumption, revealing draw- backs when using, initiating educational and other special events (for example, the classification of drug adverse reactions, the study of the structure of antibiotics consumption in different regions or individual countries in order to strengthen the fight against antibiotic resistance, etc.), as well as monitoring the outcomes of these activities. In the second half of the twentieth century the WHO proposed several uniform systematics of medicines deprived of drawbacks of the classifications used previously. They combine some classification principles such as the mechanism of drug action, indications and the chemical structure of the active pharmacological ingredient (API) that is present [3].

At present the Anatomical Therapeutic Chemical classification (ATC) system is widely used with the purpose of obtaining statistical data on the drug consumption at the regional or international level, the drug market research, needs of production, classification of adverse reactions of medicines, etc. With the help of ATC classification medicines can be encoded, their possible use in therapy, potency and composition can be determined. According to ATC classification all medicines are divided into five main groups depending on their action on a particular anatomical organ or system, and their chemical, pharmacological, therapeutic and chemical 
properties. At the first level there are 14 major anatomical groups marked with one Latin letter: A - medicines affecting the digestive system and metabolism; $\mathrm{B}-$ medicines affecting blood system and hemopoiesis; $\mathrm{C}-$ medicines affecting the cardiovascular system, etc. Each group, in turn, is divided into therapeutic / pharmacological subgroups (the second and third level). The fourth level is presented by therapeutic / pharmacological / chemical subgroups; the fifth one - by a chemical substance (API). The second - the fourth levels of medicines are often used to identify pharmacological subgroups (when it is more appropriate than determination of therapeutic and chemical subgroups). The Biopharmaceutics Classification System (BCS) considers the relationship of the three indicators - solubility of the drug substance, its dosage form dissolution and penetration of APIs from the intestine after oral use into the systemic circulation [2].

According to BCS all drug substances are divided into four classes based on solubility in biological fluids and permeability through biological membranes in the gastrointestinal tract after oral administration.

The first class (I) of BCS includes active substances with a high solubility and permeability having high indicators of absorption and bioavailability.

The second class (II) of BCS are the active substances characterized by a low solubility, but a high permeability through biological membranes, they differ by optimal indicators of absorption and bioavailability.

The third class (III) of BCS combines active substances with a high solubility, but a low permeability through biological membranes, they differ by limited absorption and bioavailability.

The fourth (IV) class includes active substances with a low solubility and low permeability, they differ by problematicity as for absorption and bioavailability [1].

The aim of the work is to prove bioequivalence of solid dosage forms on the basis of the study of physical and chemical properties of active substances using the biopharmaceutical classification system.

\section{Experimental Part}

Within the biopharmaceutical concept medicines are considered as a dialectically integrated specific physical chemical system, taking into account the impact of mandatory variables (pharmaceutical, physiological, biochemical) that acquire biological significance and influence on the drug efficiency and formation of their bioequivalence. The drug efficiency can be determined only by a careful study of the impact of both pharmaceutical and biological variables, each of which causes a dominant influence on the various stages of the "life" of a drug, beginning with creation and ending with its production and the rational use $[2,3]$.

Physical and chemical and technological properties of active substances are essential features when selecting the optimal composition of new effective and available dosage forms, as well as improvement of the quality of production of the known dosage forms that differ by the optimal life cycle at the world and domestic pharmaceutical markets.
At the current stage a new direction develops in the pharmaceutical industry; it is discovery and study of physical and chemical regularities of using medicinal substances, which affect their pharmacological action. First of all, scientists are trying to establish a relationship of the active substance on technological factors, i.e. features of the pharmaceutical technology. It has become possible due to the use of modern perfect methods of estimation of drug efficiency and mainly the possibility of determination of the content of active substances and their metabolites in biological fluids, and it is necessary when considering a question about the therapeutic equivalence of medicines. The results of these studies are widely used to improve the efficiency of medicines and reduce the risk of side effects. At this stage, the role of pharmaceutical factors has been proven. During experiments the influence of the physical condition: the degree of fractionation, solubility, polymorphism and other pharmaceutical factors on the activity of medicinal substances has been confirmed. Modern methods of predicting the shelf life of drugs in most cases based on decomposition of active substances. Using physical and chemical factors that slow down chemical reactions (temperature, $\mathrm{pH}$, light, humidity, etc.) the changes that active substances are subjected in the process of storage can be checked in the short period of time $[6,7]$.

Pharmaceutical factors have a particular impact on the therapeutic efficacy of medicines. They include five groups: chemical modification of a drug substance (salt, acid, the presence of ether bonds, complex compounds); the physical and chemical state of a drug substance (crystal form, particle sizes, the presence or absence of the charge on their surface, etc.); excipients, their nature, number, the type of dosage form and the route of administration; excipients and pharmaceutical technology $[8,9,10]$.

\section{Results and Discussion}

We believe that along with these factors it is necessary to identify the interaction of active substances and excipients, which are part of the dosage form and their impact on the therapeutic efficacy of the dosage form, dynamics and kinetics of release of the active ingredient, its bioavailability and bioequivalence.

On the example of the active substance - bisoprolol fumarate, which belongs to class I in accordance with the biopharmaceutical classification system, the kinetics of release and bioequivalence have been studied. Since according to the biopharmaceutical classification system the substance of bisoprolol fumarate belongs to class I of substances with a high solubility and permeability and has high indicators of absorption and bioavailability, in order to confirm in vitro similarities of $10 \mathrm{mg}$ tablets of bisoprolol fumarate of "Farmak" JSC with the corresponding original medicine "Concor tablets, $10 \mathrm{mg}$ " the study of the kinetics of release of the active substance (bisoprolol fumarate) was performed in 3 standard media:

1) $\mathrm{pH} 1.2$ : the mixture of $0.2 \mathrm{M}$ solution of hydrochloric acid and $0.2 \mathrm{M}$ solution of sodium chloride;

2) $\mathrm{pH} 4.5$ : the mixture of the solution of $2.99 \mathrm{~g} / \mathrm{l}$ of sodium acetate and $14.0 \mathrm{ml} / 1$ of $2 \mathrm{M}$ solution of acetic acid; 


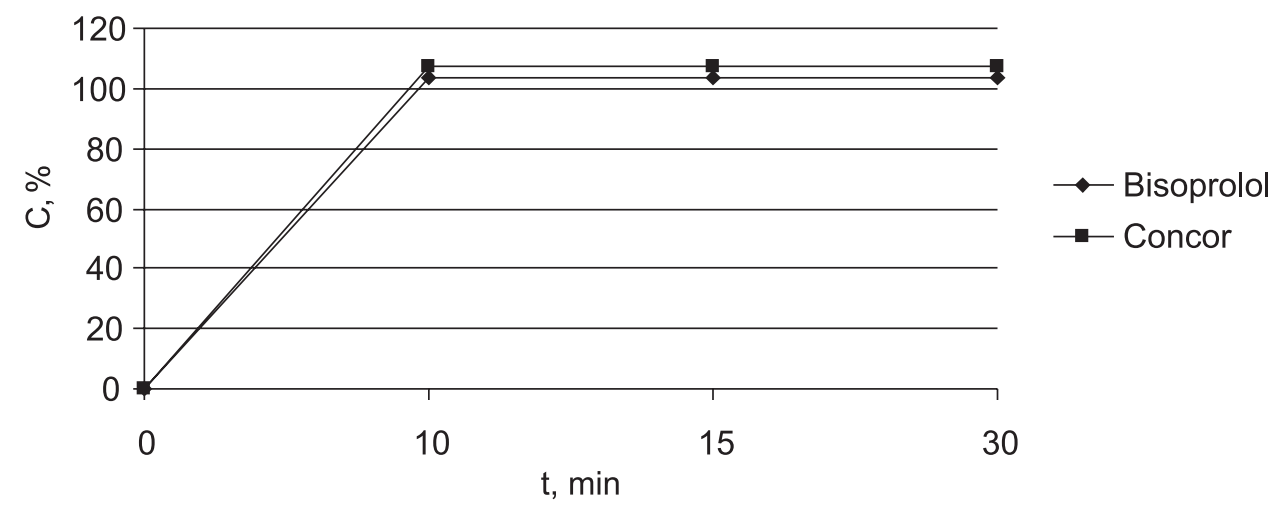

Fig. 1. The kinetics of release of the active substance of $10 \mathrm{mg}$ tablets of bisoprolol fumarate and the original medicine "Concor tablets, $10 \mathrm{mg}$ " in the $\mathrm{pH}$ medium of 1.2.

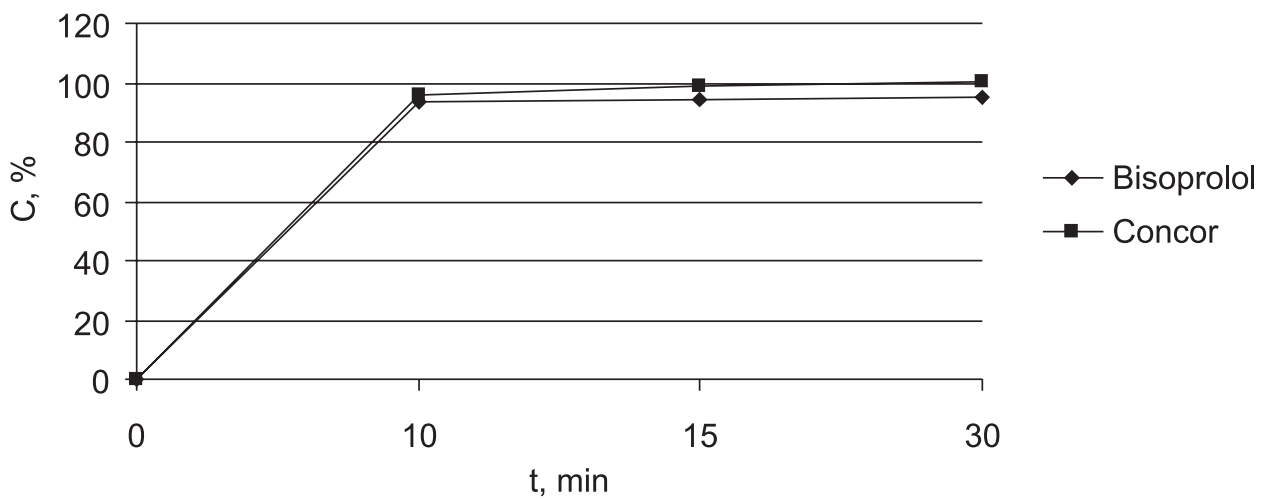

Fig. 2. The kinetics of release of the active substance of $10 \mathrm{mg}$ tablets of bisoprolol fumarate and the original medicine "Concor tablets, $10 \mathrm{mg}$ " in the $\mathrm{pH}$ medium of 4.5 .

3) $\mathrm{pH}$ 6.8: the mixture of $0.2 \mathrm{M}$ solution of potassium dihydrogen phosphate and $0.2 \mathrm{M}$ solution of sodium hydroxide.

The study of release of the active substance was performed on the devices for dissolution "Erweka DT 800 " and "Erweka DT 700". For research we used a type of the device with a basket rotating with the rate of $100 \mathrm{rpm}$.

The volume of the dissolution medium was $900 \mathrm{ml}$. The temperature of the dissolution medium maintained automatically was $37 \pm 0.5^{\circ} \mathrm{C}$. The release profiles of the active substance of $10 \mathrm{mg}$ tablets of bisoprolol fumarate and the corresponding original medicine "Concor tablets, $10 \mathrm{mg}$ " is shown in Fig. 1, 2 and 3.
As can be seen from the data, the kinetics of release of bisoprolol fumarate from $10 \mathrm{mg}$ tablets and the original medicine "Concor tablets, $10 \mathrm{mg}$ " is completely the same and does not depend on the $\mathrm{pH}$ medium of release. The full agreement of the profile and the amount of the active substance release referring bisoprolol fumarate to the first class of BCS allows to predict bioequivalence of medicines and to register them according to biowaiver.

Development of a new dosage form is a complex multistaged process of the experimental research, therefore, for optimization of development of the composition and technology of medicines under conditions of the laboratory of industrial pharmacy it is necessary to use the most effective methods and methods of biopharmaceu-

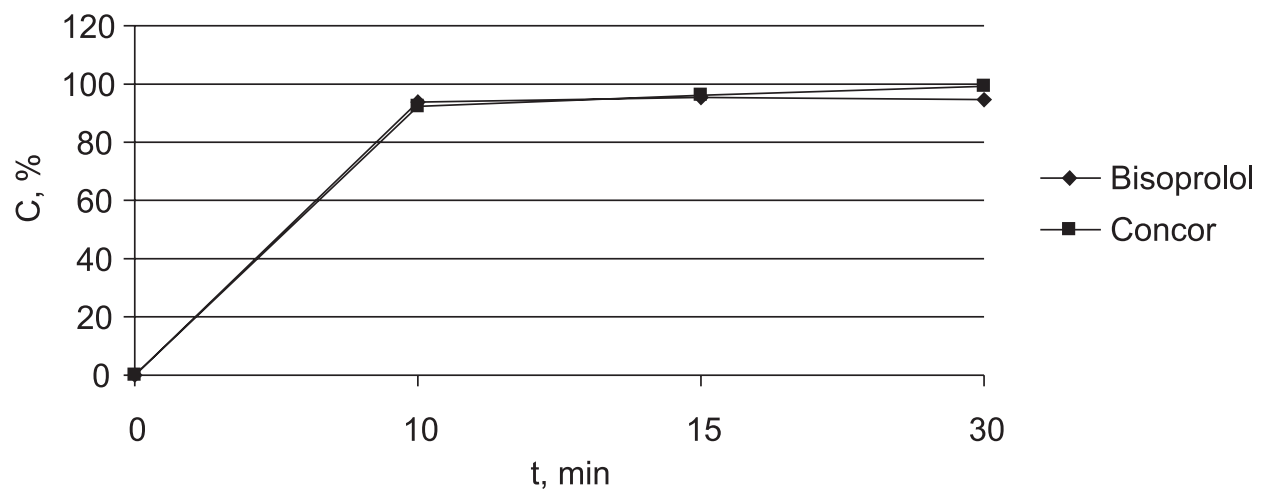

Fig. 3. The kinetics of release of the active substance of $10 \mathrm{mg}$ tablets of bisoprolol fumarate and the original medicine "Concor tablets, $10 \mathrm{mg}$ " in the $\mathrm{pH}$ medium of 6.8 . 
tical research, one of which is the research of bioequivalence of solid dosage forms based on the study of physical and chemical properties of active substances using the biopharmaceutical classification system.

\section{CONCLUSIONS}

The kinetics of release of the active ingredient $-10 \mathrm{mg}$ tablets of bisoprolol fumarate and the corresponding original medicine "Concor tablets, $10 \mathrm{mg}$ " in the $\mathrm{pH}$ me- dium of $1.2 ; 4.5 ; 6.8$ has been studied. The results obtained have shown that during the first 15 minutes under these conditions more than $85 \%$ of the active substance of both the reference medicine "Concor tablets, $10 \mathrm{mg}$ " and the test medicine "Bisoprolol tablets, $10 \mathrm{mg}$ " have been released; the release profiles of $10 \mathrm{mg}$ tablets of bisoprolol fumarate and original medicine "Concor tablets, $10 \mathrm{mg}$ " are completely the same.

\section{REFERENCES}

1. Головенко М.Я., Баула О.П., Борисюк І.Ю. Біофармачевтична класифікаиійна система. - К., 2010. $300 \mathrm{c.}$

2. Кондратенко С.Н. Фармакокинетические факторы абсорбции лекарственных препаратов: Дисс. ... докт. фарм. наук. - М., 2003. - 287 с.

3. Периев I.М., Рубан О.А., Тамм Т.I., Дмитрієвський Д.І. // Щотижневик «Аптека». - 2012. - №23 (844). C. 8 .

4. Тенцова А.И. // Фармация. - 2012. - №3. - С. 3-4.

5. Bioequivalence of bisoprolol fumarate tablets in healthy volunteers[J] / ZHOU Xia 1 DING Li 1 HE Jianchang 2 XU Gui-li 2 GUO Xiao-feng 1 CHEN Guo-wei 1 1 Department of Pharmaceutical Analysis, China Pharmaceutical University, Nanjing 210009,China; 2 Kunming General Hospital of Chengdu Military Region, Kunming 650032, China // Chinese J. of New Drugs. - 2007. - P. 20.

6. Biopharmaceutics Classifications System (BCS) / Ketoprofen. URL http://www.strinc.com // services / bcs / results/ cfm.

7. Classification of torasemide based on the Biopharmaceutics Classification System and evaluation of the FDA biowaiver provision for generic products of Class I drugs / M. Zahirul I. Khan etc. // J. of Pharmacy and Pharmacol. - 2006. - Vol. 58, Issue 11. - P. 1475-1482.

8. Drugs and pharmaceutical sciences. Modified-Release Drag Delivery Technology / Ed. by M.J.Rathbone, J.Hadgraf, M.S.Roberts. - New York - London, 2008. - Vol. 151. - 538 p.

9. Drugs and the pharmaceutical Sciences. Pharmaceutical Process Scale-Up / Ed. by M.Levin. - New YorkLondon, 2011. - Vol. 157. - 548 p.

10. Satish K. Nachaegari, Arvind K. Bansal // Pharm. Technol. - 2004. - P. 52-64.

\section{ДОСЛІДЖЕННЯ БІОДОСТУПНОСТІ ТВЕРДИХ ЛІКАРСЬКИХ ФОРМ НА ПРИКЛАДІ \\ ТАБЛЕТОК БІСОПРОЛОЛУ ФУМАРАТУ ВІДПОВІДНО ДО БІОФАРМАЦЕВТИЧНОЇ КЛАСИФІКАЦІЙНОЇ СИСТЕМИ \\ C.М.Гуреєва \\ Ключові слова: біофрармацевтична класифрікаційна система; тверді лікарські фоорми промислового виробництва; кінетика вивільнення; фрізико-хімічні властивості діючих речовин; процедура біовейвер; біоеквівалентність}

В статті обгрунтовані місце та роль біофрармацевтичної класифрікаційної системи, розкрито сутність і зміст процедури біовейвер та їх використання у фрармацевтичній розробці біоеквівалентних твердих лікарських форм. Розкрито новий напрям - відкриття та вивчення фрізико-хімічних закономірностей використання активних фрармацевтичних інгредієнтів, що впливають на їх фрармакологічну дію. Досліджено залежність діючих лікарських речовин від технологічних фракторів, тобто від особливостей фрармацевтичної технології, що стало можливим завдяки використанню сучасних досконалих методів оцінки ефективності ліків і, в основному, можливості визначення вмісту діючих речовин, їх метаболітів у біологічних рідинах, що є необхідним при розгляді питання терапевтичної еквівалентності ліків. На прикладі діючої речовини - бісопрололу фумарату, яка відноситься до першого класу у відповідності до біофрармацевтичної класифрікаційної системи, досліджено кінетику вивільнення та біоеквівалентність. Висвітлено дослідження кінетики вивільнення діючої речовини бісопрололу фрумарату з таблеток 10 мг та з відповідного оригінального лікарського засобу «Конкор, таблетки 10 мг» у середовище рH 1,2; 4,5; 6,8. Одержані результати показали, що за перші 15 хв у зазначених умовах вивільняється більше $85 \%$ діючої речовини як з препарату порівняння «Конкор, таблетки 10 мг», так і з досліджуваного препарату «Бісопролол, таблетки 10 мг». Доведено, що розробка нової лікарської форми є складним багатоступеневим процесом експериментальних досліджень, отже для оптимізації розробки складу і технології лікарських засобів в умовах лабораторії промислової фрармації необхідно використовувати найефективніші методи та методики біофармацевтичних досліджень, одним з яких є дослідження біо- 
еквівалентності твердих лікарських форм на основі вивчення фрізико-хімічних властивостей діючих речовин з використанням біофармацевтичної класифрікаційної системи.

\section{ИССЛЕДОВАНИЯ БИОДОСТУПНОСТИ ТВЕРДЫХ ЛЕКАРСТВЕННЫХ ФОРМ НА ПРИМЕРЕ ТАБЛЕТОК БИСОПРОЛОЛА ФУМАРАТА ОТНОСИТЕЛЬНО БИОФАРМАЦЕВТИЧЕСКОЙ КЛАССИФИКАЦИОННОЙ СИСТЕМЫ \\ С.Н.Гуреева}

Ключевые слова: биофармацевтическая классификационная система; твердые лекарственные фрормы промышленного производства; физиико-химические свойства действующих веществ; процедура биовейвер; биоэквивалентность

В статье обосновано место и роль биофрармацевтической классификационной системы, раскрыто сущность и содержание процедуры биовейвер, а также их использование в фрармацевтических разработках биоэквивалентных твердых лекарственных форм. Раскрыто новое направление - открытие и изучение фризико-химических закономерностей использования активных фрармацевтических ингредиентов, которые влияют на их фрармакологическое действие. Исследована зависимость действующего лекарственного вещества от технологических фракторов, то есть от особенностей фрармацевтической технологии, что стало возможным благодаря использованию современных совершенных методов оценки эфффективности лекарств и, в основном, возможности определения содержимого действующих веществ, их метаболитов в биологических жидкостях, что является необходимым при рассмотрении вопроса о терапевтической эквивалентности лекарств. На примере действующего вещества - бисопролола фрумарата, которое относится к первому классу в соответствии с биофармацевтической классификационной системой, исследованы кинетика высвобождения и биоэквивалентность. Отражено исследование кинетики высвобождения действующего вещества бисопролола фумарата из таблеток 10 мг и из соответствующего оригинального лекарственного средства «Конкор, таблетки 10 мг» в среду рН 1,2; 4,5; 6,8. Доказано, что разработка новой лекарственной фрормы является сложным многоступенчатым процессом экспериментальных исследований, следовательно для оптимизации разработки состава и технологии лекарственных средств в условиях лаборатории промышленной фрармации необходимо использовать самые эфффективные методы и методики биофрармацевтических исследований, одним из которых является исследование биоэквивалентности твердых лекарственных фрорм на основе изучения фризико-химических свойств действующих веществ с использованием биофармацевтической классификационной системы. 